Ks. Wojciech KAMCZYK*

\title{
GRZESZNA KOBIETA (LK 7, 36-50) JAKO OBRAZ KOSCIOLA W NAUCZANIU ŚW. AMBROŻEGO
}

Wspólnota wczesnochrześcijańska konfrontująca się ze starożytnym społeczeństwem, cesarstwem czy religią pogańską zmuszona była do określenia swojej tożsamości. Pisarze starochrześcijańscy i duszpasterze na wiele sposobów próbowali wyrazić, czym jest Kościół, co stanowi o przynależności do niego, jaki jest jego charakter, kim są jego członkowie. Nierzadko inspiracją dla wyrażenia tej prawdy były teksty biblijne. Jedne z nich już ze swej natury stanowiły wyraźną aluzję do kształtującej się wspólnoty wierzących, innym próbowano nadać takie znaczenie w toku interpretacji i egzegezy, często alegorycznej i symbolicznej.

Jednym z bardziej znanych autorów chrześcijaństwa zachodniego, lubującym się w egzegezie alegorycznej, był biskup Ambroży z Mediolanu ${ }^{1}$. W licznych swych dziełach, przy różnych okazjach, powołując się na bardziej i mniej znane perykopy biblijne, starał się przybliżyć czytelnikom bądź słuchaczom swoje rozumienie Kościoła ${ }^{2}$. Jednym z ciekawszych obrazów, którymi się posługiwał, jest scena opisana w Ewangelii według św. Łukasza ${ }^{3}$, jaka wydarzyła się w domu faryzeusza Szymona, kiedy to kobieta uważana za jawnogrzesznicę całowała stopy Jezusa i namaściła je wonnym olejkiem (por. Łk 7, 36-50). Ambroży dokonuje interpretacji tej perykopy przy kilku okazjach. Czyni to w Wyktadzie Ewangelii według św. Łukasza, dziele egzegetycznym, wyjaśniającym całość Ewangelii Łukaszowej . Podejmuje ten wątek także w jednej

* Ks. dr Wojciech Kamczyk - adiunkt w Katedrze Teologii Patrystycznej i Historii Kościoła na Wydziale Teologicznym Uniwersytetu Śląskiego w Katowicach; e-mail: x.wk@wp.pl.

${ }^{1}$ Por. K. Bardski, Alegoryczno-symboliczna interpretacja Biblii, Kraków 2016, 98-99; M. Simonetti, Między dostownościq a alegoriq. Przyczynek do historii egzegezy patrystycznej, thum. T. Skibiński, Kraków 2000, 281; P. Libera, Zasadnicze aspekty metody hermeneutycznej św. Ambrożego z Mediolanu, SSHT 25-26 (1992-1993) 21-25.

${ }^{2}$ Por. B. Czyżewski, Biblijne obrazy Kościoła w , Wykładzie ewangelii wedtug św. Łukasza” św. Ambrożego z Mediolanu, SG 22 (2008) 51-52.

${ }^{3}$ Scena ta ma swój odpowiednik w Ewangelii według św. Mateusza (por. Mt 26,6-13). Ambroży wie o tym i niekiedy robi aluzje do synoptycznej perykopy. Por. Ambrosius, Expositio Evangelii secundum Lucam 6, 12, ed. G. Tissot, SCh 45, Paris 1956, 232, thum. W. Szołdrski, PSP 16, Warszawa 1977, 214.

${ }^{4}$ Jest to jedyna księga Nowego Testamentu skomentowana w całości przez biskupa Mediola- 
z zachowanych mów (kazań) wygłoszonej w obecności cesarza Teodozjusza ${ }^{5}$. Tę mowę przytacza później w swoim liście do siostry Marceliny ${ }^{6}\left(\text { List } 1^{*}\right)^{7}$, wyjaśniając jednocześnie okoliczności towarzyszące jej wygłoszeniu.

Niniejszy artykuł jest próbą odpowiedzi na pytanie, w jaki sposób Ambroży, posługując się obrazem grzesznej kobiety, opisuje istotę i misję Kościoła, i w jakim stopniu interpretacja ta zależy od okoliczności, które towarzyszą wyjaśnianiu tekstu biblijnego?

1. Grzeszna kobieta jako figura Kościoła. Nawiązując do synoptycznej perykopy znajdującej się w Ewangelii według św. Mateusza biskup Mediolanu kreśli podstawowe założenia interpretacyjne analizowanej opowieści:

„Usłyszała więc owa niewiasta o przybyciu Chrystusa, weszła do domu Szymona. Nie mogłaby być owa niewiasta uzdrowiona, gdyby Chrystus nie zstąpił na ziemię. A może też dlatego weszła do domu Szymona, iż była wyrazem czegoś wyższego, a mianowicie duszy, lub też Kościoła, który przybył na ziemię, aby lud zebrał swą miłą wonią (por. 2Kor 2, 14nn)"”.

Grzeszna kobieta, która weszła do domu Szymona, to symbol duszy bądź też Kościoła ${ }^{9}$, który zbiera lud dzięki miłej woni jaką roztacza. W samym wejściu owej kobiety do domu faryzeusza dostrzec można aluzję do misji Kościoła. Jest on wezwany, by wchodzić w świat „Szymona” określanego w Ewangelii

nu. W swojej egzegezie koncentrował się on głównie na Starym Testamencie. Dzieło powstawało w dość długim czasie pomiędzy 377 a 389 r. Prawdopodobnie skompilowane zostało ze spisanych kazań św. Ambrożego, uporządkowanych i uzupełnionych po pewnym czasie od wygłoszenia. Tekst ma więc charakter żywej mowy, porusza wiele zagadnień duszpasterskich, zwiera liczne wskazówki moralne i duchowe (por. G. Tissot, Introduction, w: SCh 45, 9-10).

${ }^{5}$ Wypadki, o których mowa w kazaniu miały miejsce w 388 r. Na ten czas należy datować jego wygłoszenie. Wiadomo z pewnością, że był przy tym obecny cesarz i biskup wymógł wtedy na nim pewne ustępstwa. Całość homilii zawarta została w Liście do siostry Marceliny (List $1 *$ ), zawiera on dodatkowy komentarz do tamtych wydarzeń, dlatego w artykule powołuję się na tekst listu. Polskie thumaczenie samej mowy: św. Ambroży, Mowa w kościele w obecności cesarza Teodozjusza w sprawie spalonej synagogi, tłum. J. Czuj, w: św. Ambroży z Mediolanu, Mowy, POK 21, Poznań 2010², 296-307.

${ }^{6}$ Por. P. Szczur, Marcelina, EK XI 1226.

${ }^{7}$ List zawiera mowę św. Ambrożego wygłoszoną w obecności cesarza Teodozjusza w kwestii spalonej synagogi oraz komentarz do wydarzeń z tym związanych. Tekst łaciński listu na podstawie wydania: Sancti Ambrosi Opera, t. 3, CSEL 82, Vindobonae 1982, thumaczenie polskie wg: Św. Ambroży z Mediolanu, Listy, t. 3, tłum. P. Nowak, BOK 28 [brak oznaczenia kolejnego tomu], Kraków 2012.

${ }^{8}$ Ambrosius, Expositio Evangelii secundum Lucam 6, 13, SCh 45, 233: „Audiuit ergo mulier ista uenisse Christum, intrauit in domum Simonis, neque enim sanari potuisset haec mulier, nisi Christus uenisset in terram. Et fortasse ideo etami ipsa ingreditur domum Simonis, quo speciem habeat cuiusdam superioris animae scilicet uel ecclesiae, quae descendit in terram, ut bono odore sibi populum congregaret”, PSP 16, 215.

${ }^{9}$ Ambroży w jednym z listów do cesarza Teodozjusza (Epistula 1a*, CSEL 82, 174, BOK 28, 146) mówi wprost o grzesznej kobiecie jako o figurze Kościoła. 
według św. Mateusza „trędowatym” (por. Mt 26, 6) ${ }^{10}$. Jako że trąd nieraz bywał symbolem grzechu i wiązał się w tradycji żydowskiej z wykluczeniem ze wspólnoty ${ }^{11}$, Ambroży mógł mieć tu na myśli zadanie Kościoła polegające na głoszeniu nauki Chrystusa niewierzącym ${ }^{12}$. W osobie Szymona widział także Żydów, którzy odwrócili się od orędzia Ewangelii. Misją Kościoła jest „roztaczanie miłej woni”, zapewne nauki Chrystusa, która jest zdolna przemienić świat. Może oznaczać ono również samo postępowanie w doskonałości. Jak grzeszna kobieta, podchodząca do Jezusa, tak Kościół ciągle kroczy na drodze doskonałości zbliżając się ku Chrystusowi ${ }^{13}$.

Fakt wejścia kobiety do domu Szymona zostaje wykorzystany jeszcze w inny sposób:

„W domu faryzeusza grzesznica otrzymuje pochwały. W domu Zakonu i proroka nie faryzeusz, lecz Kościół zostaje usprawiedliwiony; faryzeusz bowiem nie wierzył, Kościół zaś uwierzył. Tamten powiedział: «Gdyby ten był prorokiem, wiedziałby zaiste, co za jedna i jaka jest ta niewiasta, która go dotyka» (Łk 7, 41). Judea zaś jest domem Zakonu, który nie jest wypisany na kamiennych tablicach, lecz na tablicach serca. W niej (w Judei) zostaje usprawiedliwiony Kościół, odtąd już wyższy od Zakonu"14.

Ambroży wskazuje na paradoks wydarzenia, które ma miejsce w domu faryzeusza. To nie Judea, to nie Żyd, ale Kościół w osobie grzesznej kobiety przyjmuje właściwą postawę i zostaje zbawiony dzięki swojej wierze. Faryzeusz jest figurą Prawa Starego Testamentu, grzeszna kobieta to figura pogan, którzy zostali zaproszeni do Kościoła, uwierzyli i zostali usprawiedliwieni ${ }^{15}$.

Motyw żydowski dostrzegany w tym wydarzeniu Ambroży eksponuje zwłaszcza w Mowie w kościele w obecności cesarza Teodozjusza w sprawie spalonej synagogi, przytaczanej w liście do siostry Marceliny. Wpatrując się w postać grzesznej kobiety, która w domu Szymona obmyła Jezusowi stopy, Ambroży stawiał pytanie o znaczenie jej gestu. Gospodarz to Żyd, który

${ }^{10}$ Autor zauważa, że Szymon nazwany jest u Mateusza „trędowatym” i wykorzystuje ten fakt w swojej egzegezie, pomimo iż u Łukasza nie ma o tym wzmianki, por. Ambrosius, Expositio Evangelii secundum Lucam 6,12-13, SCh 45, 232, PSP 16, 214-215.

${ }^{11}$ Por. G.W. Buchanan, Trad, w: Stownik wiedzy biblijnej, red. B.M. Metzger - M.D. Coogan, tłum. B. Olszewska, Warszawa 1999, 775.

${ }^{12}$ Por. Ambrosius, Expositio Evangelii secundum Lucam 6, 13, SCh 45, 232-233, PSP 16, 214-215.

${ }^{13}$ Por. tamże 6, 14, SCh 45, 233, PSP 16, 215-216.

${ }^{14}$ Tamże 6, 23, SCh 45, 235-236: „In domo Pharisaei peccatrix glorificatur, in domo legis et prophetae non Pharisaeus, sed ecclesia iustificatur; Pharisaeus enim non credidit, ista credebat. Denique ille dicebat: «si esset propheta, sciret utique quae et qualis esset mulier quae tangit eum». Domus autem legis Iudaea, quae non in lapidibus scribitur, sed in tabulis cordis. In hac iustificatur ecclesia iam lege maior", PSP 16, 218, w przekładzie polskim - dla lepszego zrozumienia tekstu - dokonano niewielkiej korekty: wyrażenie z Pisma Świętego „co zacz”, zmieniono na „co za jedna i jaka”.

${ }^{15}$ Por. Czyżewski, Biblijne obrazy Kościoła, s. 56. 
choć teoretycznie religijny, nie jest zdolny do czynu równego grzesznej kobiecie. Jako reprezentant narodu wybranego Szymon zostaje tu zdyskredytowany, przedstawiony w niekorzystnym świetle. Zabieg ten służy argumentacji przeciw cesarzowi Teodozjuszowi. Należy ją powiązać z kwestią synagogi w Kallinikum, spalonej na skutek rozruchów społecznych wywołanych przez mnichów, w Mezopotamii w 388 roku $^{16}$. Cesarz bez dochodzenia nakazał miejscowemu biskupowi odbudowanie synagogi na własny koszt ${ }^{17}$. Przeciw temu rozwiązaniu protestował Ambroży i publicznie, w czasie kazania, napominał cesarza, nawołując do odwołania decyzji ${ }^{18}$. List, zawierający wygłoszone wtedy kazanie, ukazuje więc napięcie pomiędzy Kościołem a Żydami, a biskup podkreśla wyższość chrześcijan nad postawami Żydów. Nastawienie cesarza każącego za zburzenie synagogi zostaje ocenione surowo, choć wedle współczesnych standardów wydaje się sprawiedliwe ${ }^{19}$. Kościół zaś, widziany w symbolu grzesznej kobiety, jawi się jako prawdziwa wspólnota, wierna Chrystusowi, stanowiąca widzialne przedłużenie Jego obecności w świecie.

W nawiązaniu do słów Jezusa wskazujących faryzeuszowi Szymonowi grzeszną kobietę Ambroży nauczał:

„Wszyscy tworzymy jedno ciało Chrystusa (por. 1Kor 12, 12), którego głową jest Bóg, my zaś jesteśmy członkami: jedni może są oczami - jak prorocy, [inni] zębami - jak apostołowie, którzy do naszych serc wlali pokarm ewangelicznego nauczania [...], [inni] są też jego rękami - tymi zdają się być spełniający dobre uczynki; jego brzuchem są też ci, którzy ubogim udzielają środków do życia; niektórzy są więc też jego nogami, i obym zasłużył być jego piętą!'”20

Wizja Kościoła opiera się na nauczaniu św. Pawła z 1 Listu do Koryntian. Jest on organizmem, którego głową jest Bóg, a każdy z ochrzczonych którymś z członków. Interpretacja Ambrożego posuwa się jednak dalej i jest bardziej szczegółowa. Oczy to prorocy, co sugeruje, że Ambroży docenia ich wkład w ocenę rzeczywistości, obserwowanie świata i tego, czego dokonuje w nim

${ }^{16}$ Por. E. Wipszycka, Kościót w świecie późnego antyku, Warszawa 1994, 169.

${ }^{17}$ Postępek cesarza wydaje się dość niezwykły, gdyż powszechnie Teodozjusz uważany był za wroga herezji i obrońcę ortodoksji, por. J. Jurkiewicz, Polityka religijna cesarzy IV wieku (od Konstantyna Wielkiego do Teodozjusza I), TST 25 (2006) fasc. 2, 141-142.

${ }^{18}$ Por. M. Simon, Cywilizacja wczesnego chrześcijaństwa I-IV w., thum. E. Bąkowska, Warszawa 1981, 264.

${ }^{19}$ Por. K. Ilski, Idea jedności politycznej, społecznej i religijnej w świetle pism Ambrożego z Mediolanu, Poznań 2001, 78-80; B. Czyżewski, «Cesarz jest w Kościele, a nie ponad Kościołem». Próba określenia relacji władzy kościelnej i świeckiej w IV wieku na przykładzie św. Ambrożego z Mediolanu, „Społeczeństwo i Kościół” 10 (2013) 18; M. Zelzer, „Imperator intra ecclesiam non supra ecclesiam est" (Ambrosius, Epistula 75a,36), VoxP 18 (1998) t. 34-35, 221.

${ }^{20}$ Ambrosius, Epistula 1*, 11, CSEL 82, 152: „Omnes unum Corpus Christi sumus cui caput deus, membra autem nos sumus, alii fortasse oculi ut prophetae, dentes ut apostoli qui evangelicae praedicationis cibum nostris infudere pectoribus [...], sunt et manus eius qui videntur bonorum exsecutores operum, sunt et venter eius qui vires alimoniae pauperibus largiuntur, sunt ergo et pedes eius aliqui, atque utinam merear eius esse calcaneum!", BOK 28, 126-127. 
Bóg. Zęby to Apostołowie, którzy pozwalają wnikać zdrowej nauce do całego organizmu i w ten sposób go odżywiają. Ręce to ci, którzy wykonują dobre uczynki, niejako w imieniu całego organizmu. Brzuchem są ci, którzy udzielają środków do życia ubogim, pełnią dzieła miłosierdzia ${ }^{21}$.

Sam Ambroży zaznacza, że chciałby być chociażby piętą tego organizmu. Zależy mu na przynależności do niego, a przynajmniej chce to pokazać w swojej wypowiedzi. Nie teoretyzuje, ale wyraźnie chce wskazać, jakie są zalety tej przynależności. Warto zaznaczyć, że mówiąc o organizmie nie precyzuje, czy chodzi o ciało kobiety z przypowieści, czy też samego Jezusa, nie podsuwa czytelnikowi rozwiązania, do kogo odnieść Pawłową interpretację, ale to niedopowiedzenie pozwala na głębsze rozwinięcie myśli eklezjologicznej i bardziej szczegółową interpretację perykopy.

2. Gest obmycia stóp. Kobieta, która wtargnęła do domu faryzeusza, płacze i swoimi łzami niejako obmywa stopy Jezusa. Gest obmycia nóg był dla Żydów wyrazem gościnności, otwartości i życzliwości wobec przybysza. Szymon, który gościł Jezusa, prawdopodobnie nie pokwapił się, by to uczynić22 Owa kobieta zdaje się naprawiać to zaniedbanie:

„Bliska jest nam ta (niewiasta) [...]. Dotąd bowiem nie wyrzekliśmy się naszych grzechów. Gdzie nasze łzy, nasze narzekania, nasz płacz? «Pójdźmy, pokłońmy się i upadnijmy i płaczmy przed Bogiem, Panem naszym, który nas stworzył» (Ps 94, 6), abyśmy przynajmniej do nóg Jezusa przyjść mogli. Nie możemy bowiem jeszcze przystapić do Głowy, bo grzesznik przy nogach, sprawiedliwy przy Głowie"23.

Bohaterka ewangelicznej perykopy ukazana jest jako bliska czytelnikom Ambrożego. Wydaje się, że przede wszystkim ze względu na jej grzeszność. Jej płacz i łzy stanowią dowód pragnienia wyznania grzechów, a być może nawet to wyznanie zastępują. Dlatego nieco później pojawia się zaproszenie: „Łzami wyznaj grzechy”24. Taka postawa jest związana z poszukiwaniem Bożej mądrości i sprawiedliwości, nie zaś własnej chwały. Bliska jest także poszukiwaniu prawdy, choć dotyczy samego poszukującego grzesznika ${ }^{25}$.

${ }^{21} \mathrm{~W}$ myśli tej zauważyć można pewną analogię do nauki o potrójnej misji Kościoła - Ludu Bożego, por. Katechizm Kościoła Katolickiego, Poznań 1994, 196-197 (nr 783-786).

${ }^{22}$ Zamożniejsi gospodarze pozostawiali tę czynność swojej służbie. Trudno stwierdzić, czy Szymon zaniedbał tego zwyczaju, czy po prostu wyręczył się służbą. Por. Komentarz historyczno-kulturowy do Nowego Testamentu, red. C.S. Keener - K. Bardski - W. Chrostowski, Warszawa 2000, 141.

${ }^{23}$ Ambrosius, Expositio Evangelii secundum Lucam 6, 16, SCh 45, 233-234: „Quae propinqua nobis est; non dum enim peccatis nostris renuntiauimus. Ubi sunt nostrae lacrimae, ubi gemitus, ubi fletu? «Uenite, adoremus et procidamus ante eum et ploremus ante dominum, qui fecit nos», ut saltim ad pedes Iesu uenire possimus. Nondum enim possumus ad caput uenire; peccator ad pedes, iustus ad caput", PSP 16, 216.

${ }^{24}$ Tamże 6, 17, SCh 45, 234: „Lacrimis confitere delicta”, PSP 16, 217.

${ }^{25}$ Kobieta podchodzi do Chrystusa nie z zuchwałości, ale dzięki świadomości swej grzeszności, 
Obmycie nóg gościowi oznacza docenienie przybysza i własne uniżenie. W tej postawie Ambroży dostrzega wzór dla chrześcijanina, który przyjmuje w swoim życiu Chrystusa - Boga, a jednocześnie potrafi właściwie odnieść się do drugiego człowieka ${ }^{26}$. Grzeszna kobieta, choć w tym fragmencie autor nie zaznacza tego bezpośrednio, to symbol Kościoła, który oddaje cześć Jezusowi. Czci Go i stawia na pierwszym miejscu, widzi w Nim swą Głowę, do której nie jest godzien jeszcze przystapić, dlatego oddaje cześć Jego stopom.

Postawa łez oznaczających wyznanie grzechów każe jednak autorowi odpowiedzieć na pytanie o samo zachowanie Jezusa, który na taki gest ze strony grzesznej niewiasty pozwala:

„A może dlatego Chrystus sam nie umył nóg swoich, abyśmy je obmyli swymi łzami. Dobre to łzy, które mogą nie tylko obmyć nasze winy, lecz również obmyć stopy boskiego Słowa, aby chód jego przyniósł nam obfity pożytek. Dobre łzy, które zawierają nie tylko przebaczenie grzechów, lecz także positek dla sprawiedliwych"27.

Autor rozważań stawia tezę, iż to sam Chrystus zaniedbał obmycia swych stóp, pozwalając w ten sposób człowiekowi przystapić do nich i to uczynić. Obmycie ma charakter ekspiacyjny, pozwala na zrehabilitowanie się wobec Mistrza. Formą obmycia są łzy, które stanowią nawiązanie do żalu za grzechy i pokuty. „Dobre łzy” skutkują nie tylko przebaczeniem grzechów, lecz także „posiłkiem sprawiedliwych”. O ile fakt dostapienia miłosierdzia wydaje się tu oczywisty i zrozumiały, to kwestia „posiłku sprawiedliwych” jest już mniej jasna. $Z$ jednej strony może ona stanowić zachętę do dzielenia się dobrami z tymi, którym ich brak, do nakarmienia ubogich i głodnych oraz napojenia spragnionych. Może także dotyczyć kwestii przebaczenia nawet najbardziej pogardzanym i odrzuconym ${ }^{28}$. To wyjaśnienie wydaje się być uzasadnione, zwłaszcza, że problem ten podjęty zostaje także w innych miejscach komentarza do tej perykopy ${ }^{29}$. Z drugiej strony wspomniany ,posiłek sprawiedliwych" może oznaczać szczególne łaski wynikające z pokornej postawy żalu za grzeszność dla tych, którzy są sprawiedliwi i nie muszą oskarżać się z poważnych przewinien. W tym sensie ,posiłek sprawiedliwych” to umocnienie w dobrym, wsparcie i docenienie tych, którzy prowadzą życie sprawiedliwe ${ }^{30}$.

z miłością i pokora, dlatego zostaje nagrodzona i pochwalona przez Jezusa. Por. J. Jurkiewicz, Pokora w świetle „Expositio evangelii secundum Lucam” św. Ambrożego, VoxP 28 (2008) t. 52, 366.

${ }^{26}$ Por. tamże, s. 369.

${ }^{27}$ Ambrosius, Expositio Evangelii secundum Lucam 6, 18, SCh 45, 234: „Et fortasse ideo non lauit pedes suos Christus, ut Eos lacrimis nos lauemus. Bonae lacrimae, quae non solum nostrum possunt lauare delictum, sed etami uerbi caelestis rigare uestigium, ut gressus in nobis eius exuberent. Bonae lacrimae, in quibus non solum redemtio peccatorum, sed etiam iustorum refectio est", PSP 16, 217.

${ }^{28}$ Por. tenże, Epistula 1*, 11, CSEL 82, 152, BOK 28, 127.

${ }^{29}$ Por. tamże $1 *$, 13, CSEL 82, 153, BOK 28, 128; 1*, 22, CSEL 82, 157, BOK 28, 130-131.

${ }^{30}$ Docenienie cnoty pokory w kontekście posiłku można dostrzec wyraźnie w komentarzu Am- 
Argumentacja Ambrożego pogłębia i rozszerza znaczenie gestu obmycia:

„Wylewa wodę na nogi Chrystusa także ten, kto swoje sumienie oczyszcza z brudów grzechów; bo Chrystus przechadza się w sercu każdego z nas. Strzeż się przeto, żebyś nie miał nieczystego sumienia i nie zaczął brudzić nóg Chrystusa. Strzeż się, by nie natrafił w tobie na cierń niegodziwości, który mógłby zranić jego piętę, gdy w tobie się przechadza" ${ }^{31}$.

Znak obmycia łzami jest symbolem osobistego oczyszczenia z grzechów ${ }^{32}$. Ambroży zwraca uwage na fakt obecności Chrystusa w sercu człowieka. Grzech jest tym, co uwłacza tej obecności, „,brudzi nogi Chrystusa”, utrudnia „przechadzanie się"33. Wylanie wody staje się analogia procesu pokutnego, którego podstawą i fundamentem jest najpierw uświadomienie sobie grzechu i złego postępowania. To początek kuracji zbawczej, ma istotne znaczenie dla procesu uzdrowienia ${ }^{34}$. Zatrwożenie się z powodu własnych grzechów powinno prowadzić do wyznania winy, by w ten sposób mógł zakończyć się proces oczyszczenia i uzdrowienia ${ }^{35}$.

Pełne znaczenie gestu obmycia Ambroży odczytuje jednak z perspektywy eklezjologicznej:

„Dlatego nie dał wody nogom Chrystusa faryzeusz, gdyż nie miał serca czystego od brudu wiarołomstwa. Czym bowiem mógłby oczyścić swoje sumienie ten, kto nie przyjął wody Chrystusa? Kościół zaś ma i wodę, i łzy; wodę chrztu i łzy pokuty. Albowiem wiara, która opłakuje dawne grzechy, zazwyczaj wystrzega się [popełniania] nowych. Przeto Szymon faryzeusz, który nie miał wody, z całą pewnością nie miał też i łez. Jakże bowiem mógłby mieć łzy ten, kto nie czynił pokuty? Ponieważ nie wierzył w Chrystusa, nie miał łez. Bo gdyby je miał, obmyłby [nimi] swoje oczy, żeby zobaczyć Chrystusa, którego jeszcze nie widział, mimo że razem z Nim był przy stole. Bo gdyby Go widział, na pewno nie wątpiłby w Jego moc"s3.

brożego do perykopy o zaproszonych na ucztę. Zajmowanie pierwszych miejsc w czasie posiłku, to synonim wysokiego mniemania o sobie i podkreślania własnej, wysokiej pozycji. Ci, którzy zajmą miejsce wskazane przez gospodarza, prawdziwie zostają docenieni i unikają upokorzenia. Por. Jurkiewicz, Pokora w świetle „Expositio evangelii secundum Lucam” św. Ambrożego, s. 370.

${ }^{31}$ Ambrosius, Epistula 1*,12, CSEL 82, 152: „Mittit et ille aquam in pedes Christi qui a peccatorum colluvione mundat conscientiam suam, ambulat enim Christus in pectoribus singulorum. Cave igitur ne pollutam habeas conscientiam et pedes Christi incipias inquinare. Cave ne spinam in te improbitatis offendat qua eius deambulantis in te calcaneum saucietur", BOK 28, 127.

${ }^{32}$ Por. M. Sołomieniuk, Motyw płaczu w mowach żałobnych św. Ambrożego, TPatr 7 (2010) 124.

${ }^{33}$ Ambroży apelował w ten sposób do sumienia samego cesarza, który chciał, jego zdaniem, zbyt surowo ukarać wspólnotę kościelną za wywołanie zamieszek, na skutek których ucierpiała żydowska synagoga. Por. Simon, Cywilizacja wczesnego chrześcijaństwa, s. 264.

${ }^{34}$ Por. D. Zagórski, Przebieg aktu pokutnego na podstawie «Komentarza do Psalmu XXXVII» św. Ambrożego, RT 53 (2006) z. 4, 173-174.

${ }^{35}$ Por. tamże, s. 178-179.

${ }^{36}$ Ambrosius, Epistula 1*, 12, CSEL 82, 152-153: „Ideo aquam pedibus Christi non dedit 
Porównanie grzesznej kobiety $\mathrm{z}$ faryzeuszem doprowadza autora do stwierdzenia, że to nie Szymon, ale owa kobieta, jest symbolem Kościoła. Faryzeusz jest przedstawicielem narodu żydowskiego, który pomimo posiadania wielu środków i możliwości nie przyjął należycie Chrystusa. Kościół ma moc obmywania nóg Chrystusa. Podstawą tej mocy jest wiara, której brakowało faryzeuszowi.

Środki zbliżające ku Chrystusowi to „woda chrztu” i „łzy pokuty”. Łatwo odnieść je do praktyk pierwotnego Kościoła, dla którego jeden i drugi obrzęd, niekoniecznie nazywany już wtedy sakramentem w naszym rozumieniu, miał znaczenie oczyszczające i przemieniające. W ten sposób Ambroży mówi o Kościele jako organizmie, który ciagle przechodzi proces oczyszczenia i nawrócenia. Jest zdolny do tego, gdyż wierzy w Chrystusa. Z drugiej strony Kościół jest także tym, który szafuje sakramentami, posiada narzędzia służące do oczyszczenia i posługuje się nimi służąc człowiekowi.

3. Otarcie włosami. Łzy grzesznej kobiety wyrażały jej wewnętrzną postawę, która skłaniała ją do zbliżenia się do Jezusa. Do tego samego zachęcał biskup Mediolanu, kontynuując objaśnianie fragmentu Łukaszowej Ewangelii:

„Jeśli jednak do głowy Chrystusa przystapić nie możesz, to niech Chrystus swymi stopami dotknie twojej głowy. I kraj jego szaty leczy; uzdrawiają i stopy. Rozściel przed Nim swoje włosy, rozciągnij przed Nim wszystko, co upiększa twe ciało. Nie są czymś marnym włosy, które mogą otrzeć nogi Chrystusa. Świadczy o tym ów (Samson), który póki miał włosy, był niezwyciężony (por. Sdz 16, 17). Wreszcie nie przystoi, aby niewiasta modliła się mając ogoloną głowę (por. 1Kor 11,5). W każdym razie winna mieć włosy, aby nimi mogła okrywać stopy Chrystusa, żeby tą ozdobą jej piękności i powabu ocierała stopy mądrości, aby choć najmniejsza kropla mocy Bożej tę ozdobę zrosiła"37.

Ambroży zatrzymuje się na geście otarcia stóp Jezusa przez kobietę własnymi włosami. Buduje swoją wypowiedź na aluzjach biblijnych dotyczących

pharisaeus quia mundum a colluvione perfidiae animum non habebat. Unde enim suam munda ret conscientiam qui aquam non susceperat Christi? Ecclesia autem et aquam habet et lacrimas habet, aquam baptismatis, lacrimas poenitentiae; namque fides quae superiora peccata deplorat nova cavere consuevit. Ergo Simon pharisaeus qui aquam non habebat utique et lacrimas non habebat. Quomodo enim haberet lacrimas qui poenitentiam non gerebat? Quoniam non credebat in Christum, non habebat lacrimas. Nam si habuisset lavisset oculos suos ut Christum videret, quem adhuc cum simul accumberet non videbat. Nam si vidisset non utique de eius potestate dubitasset", BOK 28, 127.

${ }^{37}$ Tenże, Expositio Evangelii secundum Lucam 6, 19, SCh 45, 234-235: „Etsi ad caput Christi adcedere non potes, tangat pedibus suis caput tuum Christus. Et fimbria curat eius et pedes curant. Expande capillos, sterne ante eum omnes tui corporis dignitates. Non mediocres capilli sunt, qui possunt pedes tergere Christi. Testatur hoc ille, qui quamdiu capillos habuit, uinci nequiuit. Denique et mulierem decaluatam orare non decet. Habeat plane capillos, quibus Christi circumuoluat uestigia, quibus suae criniculis pulchritudinis et decoris sapientiae pedes tergeat, ut extremo saltem diuinae rore uirtutis umescant”, PSP 16, 217. 
ich znaczenia. W historii Samsona włosy są symbolem niezwyciężoności. Być może zwrócenie uwagi na ten szczegół miało zaznaczyć prawdę, iż Kościół symbolizowany przez kobietę także jest niezwyciężony (por. Mt 16, 18; 28, 20).

Kościół-niewiasta powinien, według Ambrożego, mieć włosy, bo niewieście, zgodnie z napomnieniem św. Pawła, nie przystoi modlić się z ogoloną głową (por. 1Kor 11, 5). Kościół powinien wszystko oddawać swojemu Panu, Jezusowi Chrystusowi; Jemu zawierzać swoje działania, pełnić Jego wolę. Włosy niewiasty są więc tym, co posiada Kościół: z jednej strony dobrami materialnymi, które dodają mu ozdoby i piękna, z drugiej wartościami duchowymi, przez które może oddawać cześć swemu Panu.

Nie mniej istotny był dla Ambrożego gest otarcia włosami stóp Jezusa. Jego symbolikę odniósł do faryzeusza-Żyda i Kościoła:

„Nie miał włosów faryzeusz, który nie mógł znać Nazarejczyka; lecz miał je Kościół, który szukał Nazarejczyka. Włosy są uważane jak gdyby za coś zbytecznego dla ciała; jednakże gdy zostaną namaszczone [wonnym olejkiem], wydają miłą woń i są ozdobą dla głowy; jeżeli nie zostaną namaszczone olejkiem są uciążliwe. Tak samo jest $\mathrm{z}$ bogactwami: są ciężarem, jeśli nie potrafisz ich używać, jeśli nie skropisz ich wonią Chrystusa. Lecz jeśli żywisz ubogich, przemywasz ich rany i wycierasz brud, z pewnością wytarłeś nogi Chrystusa"”38.

Stwierdzenie, że faryzeusz nie miał włosów jest oczywistą przenośnią. W starożytności symbol włosów łączono z symboliką głowy. Oznaczały one zjednoczenie (włosy i głowa), w tym przypadku Ambroży mógł robić aluzję do zjednoczenia z Chrystusem, jako Głową ciała - Kościoła ${ }^{39}$. Oczywistym było, że w tej jedności nie trwał faryzeusz, natomiast była ona udziałem Kościoła. Dzięki niej Kościół może oddawać w pełni chwałę Chrystusowi, roztaczać miłą woń. Czynił to będzie jednak jedynie wtedy, gdy swoje „włosy”, to co posiada, czym jest, namaści ,wonnym olejkiem” czynów miłosierdzia. Należały one, zgodnie z doktryną i przekonaniem pierwotnego Kościoła, do uczynków pokutnych mających moc obmywania brudu grzechów ${ }^{40}$.

${ }^{38}$ Tenże, Epistula $1 *, 13$, CSEL 82, 153: „Non habebat capillos phariseus qui Nazaraeum scire non poterat, habebat ecclesia quae Nazaraeum quaerebat. Capilli velut in superfluis corporis aestimantur, idem tamen si unguantur bonum reddunt odorem et ornamento sunt capiti, si non unguantur oleo ingravant; ita sunt et divitiae, oneri sunt si his uti nescias, si non aspergas his Christi odorem. Si vero alas pauperes, laves eorum vulnera illuviemque detergas, tersisti utique pedes Christi", BOK 28, 127-128.

${ }^{39}$ Por. D. Forstner, Świat symboliki chrześcijańskiej, tłum. i oprac. W. Zakrzewska - P. Pachciarek - R. Turzyński, Warszawa 1990, 357.

${ }^{40}$ Ojcowie Kościoła $\mathrm{z}$ jednej strony zwracali uwagę na fakt, iż jałmużna wypływa $\mathrm{z}$ czysto ludzkiej sprawiedliwości, z drugiej zaś strony, że jest czynem chwalebnym i wartościowym, gdyż człowiek sam dzieli się nie tylko tym, co mu zbywa, lecz co sam uważa za konieczne dla siebie. Por. A. Beugnet, Aumone, DThC I 2564-2565; A. Młotek, Jalmużna, EK VII 739; W. Kamczyk, ,,Tota paschalis solemnitas". Teologia i duszpasterstwo w kazaniach $i$ homiliach św. Augustyna, SACh SN 12, Katowice 2012, 107-108. 
Kościół oddaje cześć Chrystusowi-Bogu na wiele sposobów. Włosy grzesznej kobiety to jedynie pretekst, by wskazać, że wszelkie dobra, i materialne, i duchowe, mogą temu służyć. Winny jednak być ukierunkowane na dzieło miłosierdzia, bo wtedy najpełniej i najdoskonalej służą Synowi Bożemu.

4. Pocałunek. Gesty obmycia i otarcia stóp Mistrza wydają się być uzupełnione przez kolejny, którego również zabrakło w postawie faryzeusza. Zwracając na to uwagę Ambroży przywołał słowa samego Jezusa:

„«Nie dałeś mi pocałunku; a ona, odkąd wszedłem, nie przestaje całować nóg moich» $(Ł k 7,45)$. Pocałunek z pewnością jest oznaką miłości. Jak więc miał dać pocałunek Żyd, który nie poznał pokoju od Chrystusa mówiącego: «Pokój zostawiam wam, pokój mój wam daję» (J 14, 27). Nie ma pocałunku Synagoga, ma go Kościół, który oczekiwał, który umiłował, który powiedział: «Niech mnie ucałuje pocałunkami swych ust!» (Pnp 1, 1). Chciał bowiem pocałunkiem Pana ugasić po kropelce żar długotrwałego pragnienia, który wzrastał w miarę oczekiwania na Jego przyjście, [chciał] tym darem nasycić swe pragnienie. I dlatego święty mówi: Otworzyłem swe usta i głosiłem Twoją chwałę (por. Ps 119, 131; 51, 17). Zatem kto chwali Pana Jezusa, całuje Go; kto Go chwali, z pewnością wierzy [w Niego]"41.

Pocałunek jest przede wszystkim wyrazem miłości. Oznacza pokój, którym dzieli się całujący z całowanym. Stanowi formę uczczenia drugiej osoby. Gest ten obecny był w liturgii od pierwszych wieków jako tzw. ,pocałunek pokoju". W czasach Ambrożego miał jeszcze miejsce w momencie ofiarowania darów ${ }^{42}$. Pocałunkiem jest dla Ambrożego także przyjmowanie Ducha Święte$\mathrm{go}^{43}$. W starożytności ,pocałunek pokoju” był jednym z elementów obrzędów udzielania sakramentu Ducha Świętego ${ }^{44}$. Pocałunek często wypływa także z pragnienia drugiej osoby, z pożądania. W sensie duchowym jest formą zaspokojenia pragnienia Chrystusa, wyrazem więzi z Nim. Takiego pocałunku oczekuje Oblubienica z Pieśni nad Pieśniami (por. 1, 1), takim pocałunkiem, zgodnie z interpretacją Ojców, złączony jest z Chrystusem Kościół ${ }^{45}$.

${ }^{41}$ Ambrosius, Epistula 1*, 14, CSEL 82, 153-154: „«Osculum mihi non dedisti, haec autem ex quo intravi non cessavit osculari pedes meos». Osculum utique insigne est caritatis. Unde ergo Iudaeo osculum qui pacem non recognovit, qui pacem non accepit a Christo dicente: «Pacem meam do vobis, pacem meam relinquo vobis». Non habet synagoga osculum, habet ecclesia quae expectavit, quae dilexit, quae dixit: «Osculetur me ab osculis oris sui». Diuturnae enim cupiditatis ardorem quem adventus dominici expectatione adoleverat osculo eius volebat stillanter extinguere, hoc explere sitim suam munere. Ideoque sanctus ait: «Os meum aperui et annuntiavi laudem tuam». Qui ergo lauda dominum Iesum osculatur eum, qui laudat credit utique”, BOK 28, 128.

${ }^{42}$ Por. M. Konieczny, Pocalunek pokoju, EK XV 901.

${ }^{43}$ Por. Ambrosius, Epistula 1*, 15, CSEL 82, 154, BOK 28, 128.

${ }^{44}$ Por. J.A. Jungmann, Liturgia pierwotnego Kościoła do czasów Grzegorza Wielkiego, thum. T. Lubowiecka, Modlitwa Kościoła 16, Kraków 2013, 141, 208-209.

${ }^{45}$ Por. Cyrillus Hierosolymitanus, Mystagogiae 5, 3, ed. A. Piédagnel, SCh 126, Paris 1966, 
Warunkiem jednak złożenia takiego pocałunku jest wiara. To ona prowadzi do usprawiedliwienia i zbawienia. Wiarę posiada Kościół oczekujący od Chrystusa pokoju i miłości. Tę wiarę także stara się nieustannie pogłębiać i rozpalać. Pocałunek oznacza ten proces poznawania Chrystusa, który dokonuje się poprzez czytanie Ewangelii. Dla Ambrożego to nie tylko samo teoretyczne poznawanie dzieła, zdobywanie znajomości pewnych faktów, ale także wewnętrzna reakcja na te fakty, podziwianie ich „pobożnym uczuciem”, przyjmowanie postawy aprobaty i poparcia dla tegoż dzieła. Wejście z Chrystusem w komunię, pogłębienie wiary następuje więc dzięki uczuciom i pozytywnemu ustosunkowywaniu się do $\mathrm{Niego}^{46}$.

Nie miał tej wiary faryzeusz Szymon, przedstawiciel synagogi, więc nie mógł złożyć tego rodzaju pocałunku:

„Jak Żyd miał dać ten pocałunek? Albowiem kto nie uwierzył w Jego przyjście, nie uwierzył też w Jego mękę; bo jak może wierzyć, że On cierpiał, skoro nie uwierzył najpierw, że przyszedł? Przeto faryzeusz nie mógł dać pocałun$\mathrm{ku}$, chyba że pocałunek zdrajcy Judasza. Lecz także Judasz nie mógł go dać; i dlatego - gdy chciał pokazać Żydom obiecany pocałunek jako znak zdrady - mówi do niego Pan: «Judaszu, pocałunkiem wydajesz Syna Człowieczego?» (Łk 22, 48). To znaczy: dajesz pocałunek ty, który nie masz miłości [wyrażanej w] pocałunku, dajesz pocałunek ty, który nie znasz zobowiązania [zawartego w] pocałunku. Szuka się pocałunku nie warg, lecz serca i umysłu" ${ }^{\prime 77}$.

Nauczając, że Żyd Szymon nie mógł dać pocałunku Jezusowi, biskupowi nie chodziło wcale o fizyczny gest, ale o wewnętrzną postawę, której nie przyjął faryzeusz. Nie uwierzył on w przyjście Chrystusa. Z pewnością brak tej wiary, wspomniany tutaj, oznacza odrzucenie prawdy o tym, że On jest Mesjaszem oczekiwanym przez Żydów. Nieprzyjęcie tej prawdy skutkowało odrzuceniem wartości Jego męki. Pocałunek, który ewentualnie mógłby złożyć Szymon, duszpasterz z Mediolanu przyrównał do pocałunku Judasza. Akt ten byłby formą zdrady i wiarołomstwa. Bo $\mathrm{z}$ aktem zewnętrznym wiąże się pewne wewnętrzne zobowiązanie, a tego nie miał i niech chciał podejmować faryzeusz. Fałszywość jego pocałunku opiera się na sprowadzeniu go jedynie do zewnętrznej formy, bez wewnętrznego usposobienia - miłości. Ambroży zapewnia, że w takim pocałunku nie ma słodyczy, gdyż brak w nim wiary

148, thum. W. Kania, w: Cyryl Jerozolimski, Katechezy przedchrzcielne i mistagogiczne, BOK 14, Kraków 2000, 339-340. Zob. Forstner, Świat symboliki chrześcijańskiej, s. 21.

${ }^{46}$ Por. Ambrosius, Epistula 1*, 15, CSEL 82, 154, BOK 28, 128.

${ }^{47}$ Tamże 1*, 16, CSEL 82, 154-155: „Unde hoc Iudeo osculum? Qui enim non credidit in adventum eius nec in passionem eius credidit; quo modo enim credit passum quem venisse non credidit? Non ergo osculum habebat pharisaeus nisi forte Iudae proditoris. Sed nec Iudas habebat ideoque cum Iudaeis promissum osculum tamquam signum proditionis vellet ostendere dicit ei dominus: «Iuda, osculo filium hominis tradis?» Hoc est osculum offers qui non habes osculi caritatem, osculum offers qui nescis osculi sacramentum. Osculum non labiorum quaeritur sed cordis et mentis", BOK 28, 129. 
i miłości ${ }^{48}$. Dlatego właściwym i naturalnym autorem pocałunku jest Kościół. Biskup podkreślał tę prawdę posługując się znanymi i popularnymi obrazami:

„Kościół zaś nie przestaje całować nóg Chrystusa, i dlatego w Pieśni nad Pieśniami domaga się nie jednego, lecz wielu pocałunków (por. Pnp 1, 1), gdyż - jak święta Maryja - słucha uważnie wszystkich Jego mów, [stara się] uchwycić wszystkie Jego słowa, gdy jest czytana Ewangelia lub [księga któregoś] proroka i wszystkie Jego wypowiedzi zachowuje «w swym sercu» (por. Łk 2, 51). Przeto tylko Kościół może dawać Mu pocałunki jako Jego oblubienica; bo pocałunek jest zadatkiem zaślubin i zapowiedzią małżeństwa. Jak może dać pocałunki Żyd, który jeszcze nie wie, że Oblubieniec przyszedł?"49

Obrazem i figurą Kościoła jest Maryja, Matka Jezusa Chrystusa. Autor czyni tu aluzję do Łukaszowej Ewangelii, gdzie pisarz przypomina postawę Maryi wobec wydarzeń z życia Jezusa, zachowującą wspomnienia w swoim sercu i rozważająca je. Kościół podobnie jest tym, który przyjmuje słowa Ewangelii i słowa proroków, rozważa je w swoim łonie i zachowuje je ${ }^{50}$. W wypowiedzi Ambrożego dochodzi do głosu także wyobrażenie Kościoła jako Oblubienicy Chrystusa. Związane jest ono nie tylko z aluzją do fragmentu Księgi Pieśni nad Pieśniami (por. Pnp 1, 1), lecz także z teologią Ambrożego, w której pojawia się ten popularny już w IV w. wątek ${ }^{51}$.

Kościół nieustannie całuje Chrystusa jako Jego Oblubienica wtedy właśnie, gdy słucha Jego słów i je zachowuje. Pocałunki te są prawdziwymi pocałunkami, gdyż wypływają z miłości. Są według Ambrożego zapowiedzią zaślubin i małżeństwa, które w tym wypadku można by rozumieć jako przyszłe połączenie się z Chrystusem w Jego królestwie. Z tego też powodu skrytykowana zostaje postawa Szymona - Żyda, nie wierzącego w przyjście Mesjasza. Nie może on nawet dać Chrystusowi pocałunku, bo nie dostrzega w Nim Oblubieńca. Jego lud zostaje odrzucony i zastapiony Kościołem, który nie tylko dostrzegł w Jezusie Mesjasza, ale i pokochał jak Oblubieńca ${ }^{52}$.

${ }^{48}$ Por. tamże $1^{*}, 17$, CSEL 82, 155, BOK 28, 129.

${ }^{49}$ Tamże $1^{*}, 18$, CSEL 82, 155: „Ecclesia autem non cessat osculari pedes Christi et ideo non unum sed multa oscula in Canticis canticorum exigit, quae velut sancta Maria ad omnes eius est intenta sermones, omnia eius verba excipit, cum legitur evangelium vel propheta, et omnia eius dicta conservat in corde suo. Sola ergo ecclesia habet oscula quasi sponsa, osculum enim pignus est nuptiarum et praerogativa coniugii. Unde Iudaeo oscula qui non credit in sponsum, unde Iudaeo oscula qui adhuc sponsum venisse non novit?", BOK 28, 129.

${ }^{50}$ Nie wszyscy autorzy dostrzegają ten aspekt postawy Maryi, obecny u Ambrożego. Zwykle zwraca się uwagę na dziewictwo Maryi, która wydała na świat Bożego Syna za sprawą Ducha Świętego, por. Czyżewski, Biblijne obrazy Kościoła, s. 52; A. Santorski, Eklezjologiczne elementy mariologii świętego Ambrożego, VoxP 18 (1998) t. 34-35, 119.

${ }^{51}$ Por. J.N.D. Kelly, Poczatki doktryny chrześcijańskiej, thum. J. Mrukówna, Warszawa 1988, 301-306; H. Pietras, Poczqtki teologii Kościoła, Kraków 2000, 41-44.

${ }^{52} \mathrm{~W}$ podobny sposób o relacji naród żydowski - Kościół wypowiadają się i inni Ojcowie Kościoła. Por. Pietras, Poczatki teologii, s. 44-45. 
5. Namaszczenie oliwą. Omawiając zdarzenie, które miało miejsce w domu Szymona Ambroży nie pomija również gestu namaszczenia stóp Jezusa wonnym olejkiem przez grzeszną kobietę. Sam Jezus wiąże ten gest z zapowiedzią swojej śmierci i pogrzebu. Biskup zdaje się dostrzegać jeszcze inny, ukryty sens tego zdarzenia. Przywołując postawę faryzeusza, który nie kwapił się, by namaścić swego gościa, pisał:

„Kościół zaś ma oliwę, którą leczy rany swoich [dzieci], żeby niebezpieczeństwo nie rozszerzało się w głąb rany, ma oliwę, którą otrzymał po kryjomu. Tą oliwą Aser obmył swoją nogę, jak jest napisane: «Błogosławiony syn Aser, i będzie» poważany «przez braci», i zanurzy swą «nogę w oliwie» (Pwt 33, 24). Tą więc oliwą Kościół namaszcza karki swoich synów, aby przyjęli jarzmo Chrystusa; tą oliwą namaścił męczenników, aby oczyścić z nich światowy pył; tą oliwą namaścił wyznawców, aby nie ulegli zmęczeniu, aby strudzeni nie poddali się i nie zostali pokonani przez żar [namiętności] tego świata; dlatego namaścił ich, aby duchowa oliwa ich orzeźwiła"53.

Namaszczenie to ,gest” Kościoła posiadającego „oliwę” leczącą ,rany swoich dzieci”. Wyjaśniając to stwierdzenie biskup odwołał się do starotestamentalnego błogosławieństwa, które miał wypowiedzieć Mojżesz nad Izraelem przed swoją śmiercią, zapisanego pod koniec Księgi Powtórzonego Prawa. Członkowie pokolenia Asera, jednego z synów Jakuba - Izraela, mieli cieszyć się w Ziemi Obiecanej poważaniem ze strony współbraci, innych członków narodu wybranego, a jednocześnie ich „nogi” miały „zanurzyć się w oliwie". Egzegeci widzą w tych słowach aluzję do żyznych terenów zamieszkałych przez potomków tego rodu ${ }^{54}$. Ambroży mógł w ten sposób wskazać na Kościół, jako na „żyzne środowisko”, takie, które daje życie w sensie duchowym, leczy rany, podobnie jak oliwa, pozwala przetrwać przeciwności i prześladowania ${ }^{55}$.

${ }^{53}$ Ambrosius, Epistula 1*,20, CSEL 82, 156: „Ecclesia autem habet oleum quo suorum vulnera fovet, Ne duritia vulneris alte serpat, habet oleum quod accepit absconse. Hoc oleo Aser pedem suum lavit sicut scriptum est: «Benedictus Filius Aser et erit acceptus fratribus suis et intinget in oleo pedem suum». Hoc oleo ergo ecclesia unit filio rum services suorum ut suscipiant iugum Christi; hoc oleo unit martyres ut saecularem ab his pulverem detergeret; hoc oleo confessores unit ne labori cederent, ne succumberent fatigati, ne aestu mundi istius vincerentur; ideo unxit eos ut hos spiritale oleum refrigeraret”, $\mathrm{BOK} 28,130$.

${ }^{54}$ Posiadanie urodzajnych ziem oraz dobrobyt przepowiedział potomkom Asera już patriarcha Jakub (por. Rdz 49, 20). Proroctwo Mojżesza stanowi jego kontynuację (por. Pwt 33, 24-25). W Palestynie Aseryci osiedlili się na zachodnich stokach Gór Galilejskich, wzdłuż Morza Śródziemnego, poprzez Góry Karmelu, aż do Równiny Szaronu. Por. P. Bosak, Leksykon wszystkich postaci biblijnych, Kraków 2015, 178.

${ }^{55}$ Oliwa, którą produkowano z owoców drzew oliwnych, bardzo wytrzymałych i długowiecznych, była wypróbowanym środkiem leczniczym, łagodziła ból, pomagała w gojeniu ran, wzmacniała znużone członki, chłodziła i wygładzała skórę, chroniła przed szkodliwymi wpływami. Nie dało się jej zmieszać z wodą, jedynie z płynami o podobnych właściwościach. Starożytni byli prze- 
„Oliwa” służy Kościołowi do namaszczania „karków swych dzieci”. Wydaje się, że w przytoczonym fragmencie autor zwraca uwagę na obrzędy namaszczenia odpowiadające współczesnym gestom związanym z sakramentami chrztu, bierzmowania, kapłaństwa i chorych. W czasach Ambrożego olejem namaszczano także katechumenów, co oznaczało uzbrojenie do walki z mocami ciemności i grzechem, oraz pokutników i apostatów ${ }^{56}$. Namaszczenie, o którym tu mowa, jest jarzmem Chrystusa, oznacza przynależność do Niego, pozwala stać się Jego świadkiem. Wymienieni przy tej okoliczności męczennicy i wyznawcy są niejako potwierdzeniem, że każdy wierzący wezwany jest do podejmowania tego trudu świadectwa i otrzymuje potrzebne łaski i siły, by sprostać temu zadaniu, nie poddać się namiętnościom świata, nie dać się przykryć światowemu pyłowi, by zostać orzeźwionymi duchową oliwą. „Namaszczenie karku” może także odnosić się do postawy pokory i gotowości do pokuty za grzechy. W tej postawie nie trwał faryzeusz Szymon, Kościół zaś usposabia do jej przyjęcia ${ }^{57}$.

Ambroży jednak nie zawęża symboliki namaszczenia jedynie do kwestii sakramentów i tego, co czyni Kościół. W swojej interpretacji zwraca uwagę na aspekt bardziej indywidualny, który jednakże nadal odnosi do całej wspólnoty:

„Pojmij, jak ciało Syna (Bożego) pachnie namaszczone wonnym olejkiem. To ciało zostało zdjęte, ale nie utracone. Jego ciałem są nauki Pism. Kościół jest Jego Ciałem (por. Ef 1, 23). Jesteśmy wonnością Jego ciała (por. 2Kor 2, 15). Toteż należy się, abyśmy ozdobili martwe Jego ciało. Choć ono nie potrzebuje naszych ozdób, ale potrzebują tego ubodzy. Ozdobię Jego ciało, gdy będę głosicielem Jego nauk i zdołam wyjaśnić poganom tajemnicę Jego krzyża"s8.

Jezus, reagując na czyn grzesznej kobiety, zwrócił uwagę, że namaszczenie jest przygotowaniem na dzień Jego pogrzebu, zgodnie zresztą ze zwyczajem Żydów i wielu ludów starożytnych ${ }^{59}$. To ciało zostało zdjęte z krzyża, złożone w grobie. Nie zostało utracone, chociaż Chrystus zmartwychwstał. Tym ciałem jest nadal Kościół, a nawet nauki Pisma. To ciało nadal wydziela miły zapach i nadal potrzebuje namaszczenia. Dlatego biskup zachęca, by tego

konani, że można uspokoić wzburzone, morskie fale, wylewając na nie oliwę. Do tych właściwości oliwy nawiązywała jej symbolika. Por. Forstner, Świat symboliki chrześcijańskiej, s. 172.

${ }^{56}$ Por. tamże, s. 173-174.

${ }^{57}$ Por. Ambrosius, Epistula 1*, 19, CSEL 82, 156, BOK 28, 129-130; tamże 1*, 21, CSEL 82, 156-157, BOK 28, 130; tenże, Expositio Evangelii secundum Lucam 6, 17, SCh 45, 234-235, PSP $16,216$.

${ }^{58}$ Tenże, Expositio Evangelii secundum Lucam 6, 33, SCh 45, 240: „Intellege quemadmodum corpus fili unguentum oleat. Corpus illud est quod exutum est, non quod amissum est. Corpus eius traditiones sunt scripturarum, corpus eius ecclesia est. Corporis eius odor sumus, et ideo decet ut mortem corporis eius ornemus, etsi nostros illa non requirat ornatu, sed requirunt pauperes. Ornabo corpus eius, si fiam sermonum eius praedicator et possim gentibus crucis aperire mysterium", PSP 16, 222.

${ }^{59}$ Por. Forstner, Świat symboliki chrześcijańskiej, s. 172. 
namaszczenia dokonywać, poprzez wspieranie jego członków dziełami miłosierdzia. Będzie to stanowić najpiękniejszą ozdobę, jaką można ukoronować Jego ciało.

Na szczególną uwagę zasługuje określenie Ambrożego dotyczące Jezusa, że „Jego ciałem są nauki Pism”. To nietypowe porównanie wskazuje na bezpośredni związek Chrystusa ze słowem głoszonym w Jego imię. Nieco dalej biskup Mediolanu stwierdza, że ozdabiamy ciało Chrystusa głosząc Jego naukę i wyjaśniając poganom tajemnicę Jego krzyża. Ten, kto głosi Chrystusa, rozlewa na cały Kościół olejek swej wiary. Kościół będący ciałem Chrystusa karmi się wiarą swoich członków. Każdy wierzący zatem wezwany jest do tego, by swoją pracą i wysiłkiem zdobywania cnót budować to ciało. W postawie wierzących wobec Kościoła powtarza się więc gest grzesznej kobiety uczyniony wobec Jezusa ${ }^{60}$. Wydaje się więc, że głoszenie Ewangelii, przepowiadanie Bożej miłości, biskup Mediolanu uznaje za najważniejszy i jednocześnie eklezjotwórczy czyn miłosierdzia.

Ten aspekt namaszczenia jako aktu miłosierdzia rozwija autor jeszcze w innym miejscu:

„Chrystus raz umarł, raz został pogrzebany, ale chce, by codziennie był wylewany wonny olejek na Jego nogi. Na jakie więc nogi go wylewamy? Nogami Chrystusa są ci, o których mówi: «Co uczyniliście jednemu z tych najmniejszych, Mnieście uczynili» (Mt 25, 40). Te nogi ochładza owa kobieta w Ewangelii, obmywa je swymi łzami (por. Łk 7, 38); kiedy odpuszcza się grzech ostatnim, jest obmywana wina, darowane przebaczenie. Te nogi całuje ten, kto miłuje nawet ostatnich ze świętego ludu; te nogi namaszcza wonnym olejkiem ten, kto nawet najbiedniejszym okazuje swoją łaskawość. W nich męczennicy, w nich apostołowie, w nich sam Pan Jezus - jak oznajmia - jest czcią otaczany" $"$.

Szczytem miłosierdzia wyświadczanego innym wydaje się w tym kontekście być przebaczenie, darowanie win. Bliskie jemu jest także świadczenie pomocy ubogim i najmniejszym we wspólnocie Kościoła. W pewnym sensie

${ }^{60}$ Ambroży przypominał także, że Judasz zaproponował sprzedaż olejku, by w ten sposób zdobyć pieniądze dla ubogich. Być może niektórzy ze współczesnych biskupa Mediolanu interpretowali ten fragment uważając, że jest to sugestia zakupienia wiary dla pogan. Ambroży wskazywał, że wiara pogan okupiona została krwią Chrystusa i stąd zasadność namaszczenia Jezusowi stóp tak drogim olejkiem. Por. Ambrosius, Expositio Evangelii secundum Lucam 6, 30, SCh 45, 238-239, PSP 16, 221; tamże 6, 34, SCh 45, 240, PSP 16, 223.

${ }^{61}$ Tenże, Epistula 1*,23, CSEL 82, 155: „Semel mortuus est Christus, semel sepultus est et cottidie vult in pedes suos mitti unguentum. In quo ergo pedes mittimus? Pedes Christi illi sunt de quibus dicit: «Quod uni horum minimorum fecistis mihi fecistis». Hos pedes illa mulier evangelica refrigerat, hos lacrimis suis rigat; quando infimis peccatum remittitur, culpa lavatur, donatur indulgentia. Hos pedes osculatur qui etiam infimos plebis sacrae diligit; hos pedes unguento ungit qui etiam tenuioribus mansuetudinis suae impertit gratiam. In his se martyres, in his apostoli, in his ipse dominus Iesus honorari indicat", BOK 28, 131. 
jest to naśladowanie samego Chrystusa w dźwiganiu Jego krzyża ${ }^{62}$. Ambroży sugeruje, że akty te podobne także są do czci i kultu okazywanego Apostołom i męczennikom, które to akty z pewnością o wiele łatwiej przychodziły jemu współczesnym, niż dzieła miłosierdzia wobec drugich. W tym sensie namaszczenie także jest jałmużną, o której mowa była już wcześniej.

Akty miłosierdzia, których spełnianie jest w życiu chrześcijan tak ważne, stanowią też depozyt całego Kościoła. Ambroży rozważa:

„A może tego wonnego olejku nikt inny, jak tylko Kościól, dostarczyć nie zdoła. Ten bowiem posiada niezliczone kwiaty, roztaczające rozmaite zapachy. Kościół słusznie usposobił sobie postać grzesznicy, bo i Chrystus przyjął postać grzesznika. Toteż nikt nie może tak bardzo (Pana) miłować (por. Łk 7, 47), jak Kościół, który poprzez wielu kocha"63.

Kościół mocny wiarą i miłością wszystkich swoich członków kocha i wierzy doskonale. W tym Kościele kochali Pana i św. Piotr i św. Paweł, choć sami także byli niedoskonali. W nim może kochać Chrystusa każdy wyznawca, nawet największy grzesznik ${ }^{64}$. Kościół reprezentowany w omawianym fragmencie przez grzeszną kobietę składa się z wielu grzeszników i przez wielu grzeszników jest w nim kochany Chrystus. Olejek, który grzeszna kobieta wylała na stopy Jezusa, jest symbolem chwały i czci, wiary i miłości, jakimi ludzkość powinna obdarzyć Chrystusa Pana ${ }^{65}$.

Gest namaszczenia stóp Jezusa ma więc u Ambrożego co najmniej podwójne znaczenie. $Z$ jednej strony symbolizuje sakramenty, tajemnice wiary, przez które Kościół prowadzi do zbawienia swoich członków. Z drugiej strony oznacza dzieła miłości i miłosierdzia, które są okazywaniem czci ciału Chrystusa - Kościołowi. Największe jednak spośród nich to przebaczenie i głoszenie Ewangelii, również tym, którzy do Kościoła nie należą, a więc poganom. Kościół jest tu zatem i podmiotem i przedmiotem swojego uświęcającego działania.

Alegoryczna egzegeza Ambrożego zastosowana do perykopy o spotkaniu Jezusa z jawnogrzesznicą w domu faryzeusza Szymona jest przykładem eklezjologicznej interpretacji tekstu nowotestamentalnego. Autor w postaci głównej bohaterki dostrzegł obraz Kościoła pozostającego w relacji do Chrystusa:

${ }^{62}$ Por. tenże, Expositio Evangelii secundum Lucam 6, 34, SCh 45, 241, PSP 16, 223.

${ }^{63}$ Tamże 6, 21-22, SCh 45, 235: „Et fortasse istud unguentum non possit alius nisi ecclesia sola deferre, quae diuersi spiraminis innumerabiles habet flores, quae merito speciem accipit peccatricis, quia Christus quoque formam peccatoris accepit. Et ideo nemo potest tantum diligere quantum illa quae in pluribus diligit”, PSP 16, 218.

${ }^{64}$ Por. tamże 6, 22.

${ }^{65}$ Por. tamże 6, 29, SCh 45, 238, PSP 16, 221. 
„Zatem Kościół i obmywa nogi Chrystusa, i wyciera je swymi włosami, namaszcza je oliwą i polewa wonnym olejkiem, gdyż nie tylko leczy poranionych i pokrzepia zmęczonych, lecz także skrapia ich miłą wonią łaski i tę samą łaskę wylewa nie tylko bogatym i możniejszym, lecz również ludziom należącym do prostego ludu, waży wszystkich na tej samej szali, wszystkich przyjmuje na tej samej piersi, ogrzewa na tym samym łonie"66.

W słowach tych można dopatrzyć się podsumowania nauki Ambrożego o Kościele na podstawie omawianej perykopy. Kobieta prowadząca życie grzeszne jest obrazem Kościoła rozumianego jako wspólnota wierzących, stanowiących jeden organizm, w którym różne członki wzajemnie się uzupełniają ${ }^{67}$. Nieustannie dąży on do doskonałości, pogłębiając swą więź z Chrystusem poznaje Go coraz lepiej. Jego najważniejszym zadaniem jest oddawanie czci, wiara w Niego, przyozdabianie Go (podobnie jak ozdobą kobiety są włosy), pełnienie Jego woli i miłość (czego symbolem jest pocałunek).

Zachowanie się bohaterki wspomnianej perykopy prezentuje charakter i misję wspólnoty Kościoła. Jej pokora i łzy to symbol wspólnoty nie tylko wezwanej do pokuty, ale też posiadającej odpowiednie narzędzia do tego, by tę pokutę podjąć i dostąpić oczyszczenia. Ambroży wyraźnie wskazuje tu na chrzest i publiczną pokutę, których szafarzem jest Kościół. Mówi również o duchowej pomocy, jakiej udziela on powstającym z grzechów.

Ważnym zadaniem Kościoła jest karmienie się słowem Bożym i głoszenie Ewangelii, przekazywanie nauki Chrystusa. Wzorem w tym względzie jest dla Niego również Maryja, która stanowi przykład słuchania i zachowywania słów Chrystusa w swoim sercu. Misją Kościoła jest także pełnienie dzieł miłosierdzia, nie tylko wobec swoich członków, ale też wobec niewierzących. Do dzieł tych nie należą jednak tylko dzieła dotyczące spraw materialnych, ale również kwestie duchowe - nauczanie Ewangelii i przebaczenie grzechów.

O ile Wykład ewangelii wedtug św. Łukasza ma charakter raczej ogólny i neutralny, o tyle już w liście do siostry Marceliny, w którym przytoczona została mowa Ambrożego wygłoszona w obecności cesarza, wyraźnie zaznacza się rys antyjudaistyczny. Wynika on z chęci obrony biskupa i chrześcijan w Kallinikum, którzy brali udział w spaleniu żydowskiej synagogi. Interpretacja biskupa zmierza więc dodatkowo do ukazania Kościoła, wspólnoty chrześcijan, jako wyższego od wspólnoty i religii judaistycznej.

Kościół służy Chrystusowi przez posługę tym, którzy są Jego częścią i należą do Jego organizmu. Nie ma względu na to, kim są jego członkowie, jakiego są stanu, na ile są zamożni. Powołany jest on do służby w zakresie

${ }^{66}$ Tenże, Epistula 1*, 22, CSEL 82, 156-157: „Ecclesia igitur et lavat pedes Christi et capillis suis tergit et oleo unguit et perfundit unguento quia non solum saucios curat et lassos fovet verum etiam suavi gratiae odore respergit nec divitibus tantum et potioribus sed etiam plebeiae familiae viris eandem transfundit gratiam, aequa omnes lance examinat, omnes eodem sinu suscipit, eodem gremio fovet", BOK 28, 130-131.

${ }^{67}$ Por. tamże $1^{*}, 26$, CSEL 82, 160, BOK 28, 133. 
materialnym, doczesnym, a także duchowym, wiecznym. Każdego „waży na tej samej szali”. Nie może spodziewać się prerogatyw cesarz, tak samo wymagająco traktowany jest prosty człowiek. Wszystkich w ten sam sposób widzi, napomina, prowadzi ku zbawieniu.

Nauka Ambrożego o Kościele, ujęta w obraz grzesznej kobiety, prezentuje podstawowe elementy świadomości tego, czym jest Kościół. Na pierwszy plan wysuwa się Jego misja i zadania, jakie winien wypełniać. Charakterystycznym jest jednak odniesienie tej nauki do Chrystusa, bez którego istnienie Kościoła nie miałoby sensu.

\section{SINFUL WOMAN (LK 7:36-50) AS AN IMAGE OF THE CHURCH IN THE TEACHING OF ST. AMBROSE}

\section{(Summary)}

St. Ambrose belongs to these Fathers of the Western Church, who in their thoughts used biblical motifs using the allegorical exegesis. It was of particular significance to him to teach about the Church. While approaching the matter of the Church he referred to an interesting image from the Gospel of St. Luke, relating to a sinful woman who washed and wiped the feet of Jesus in the house of Simon, the Pharisee. In this figure different motifs of contemporary eccesiology are combined. The Church stands as one body composed of many members following together to Jesus and bowing in front of him. He is a dispenser of grace. His primary tasks are to glorify the God, transmit the Gospel and the works of mercy.

Key words: St. Ambrose Church, ecclesiology, allegorical exegesis, mercy.

Słowa kluczowe: św. Ambroży, Kościół, eklezjologia, egzegeza alegoryczna, miłosierdzie.

\section{BIBLIOGRAFIA}

\section{Źródła}

Ambrosius, Expositio Evangelii secundum Lucam, ed. G. Tissot, SCh 45, Paris 1956, thum. W. Szołdrski: św. Ambroży z Mediolanu, Wykład ewangelii według św. Łukasza, PSP 16, Warszawa 1977.

Ambrosius, Epistula 1*, ed. M. Zelzer, CSEL 82, Vindobonae 1982, 145-161, thum. P. Nowak: Św. Ambroży z Mediolanu, Listy, t. 3, BOK 28 [brak oznaczenia kolejnego tomu], Kraków 2012, 121-134; tłum. J. Czuj, w: Św. Ambroży z Mediolanu, Mowy, POK 21, Poznań 2010², 296-307.

Cyrillus Hierosolymitanus, Mystagogiae, ed. A. Piédagnel, SCh 126, Paris 1966, thum.

W. Kania, w: Cyryl Jerozolimski, Katechezy przedchrzcielne i mistagogiczne, BOK 14, Kraków 2000, 319-345.

Katechizm Kościoła Katolickiego, Poznań 1994. 


\section{Opracowania}

Komentarz historyczno-kulturowy do Nowego Testamentu, red. C.S. Keener - K. Bardski - W. Chrostowski, Warszawa 2000.

BARDSKi K., Alegoryczno-symboliczna interpretacja Biblii, Kraków 2016.

Beugnet A., Aumone, DThC I 2561-2571.

BosaK P., Leksykon wszystkich postaci biblijnych, Kraków 2015.

Buchanan G.W., Trad, w: Stownik wiedzy biblijnej, red. B.M. Metzger - M.D. Coogan, tłum. B. Olszewska, Warszawa 1999, 775.

CzyżEwski B., Biblijne obrazy Kościoła w ,, Wykładzie ewangelii wedtug św. Łukasza” św. Ambrożego z Mediolanu, SG 22 (2008) 51-61.

Czyżewski B., "Cesarz jest w Kościele, a nie ponad Kościołem». Próba określenia relacji władzy kościelnej i świeckiej w IV wieku na przykładzie św. Ambrożego z Mediolanu, „Społeczeństwo i Kościół” 10 (2013) 11-23.

Forstner D., Świat symboliki chrześcijańskiej, tłum i oprac. W. Zakrzewska - P. Pachciarek - R. Turzyński, Warszawa 1990.

ILsKi K., Idea jedności politycznej, społecznej i religijnej w świetle pism Ambrożego z Mediolanu, Poznań 2001.

Jungmann J.A., Liturgia pierwotnego Kościoła do czasów Grzegorza Wielkiego, thum. T. Lubowiecka, Modlitwa Kościoła 16, Kraków 2013.

Jurkiewicz J., Pokora w świetle „Expositio evangelii secundum Lucam” św. Ambrożego, VoxP 28 (2008) t. 52, 365-372.

Jurkiewicz J., Polityka religijna cesarzy IV wieku (od Konstantyna Wielkiego do Teodozjusza I), TST 25 (2006) fasc. 2, 131-144.

KAмczyк W., ,, Tota paschalis solemnitas”. Teologia i duszpasterstwo w kazaniach $i$ homiliach św. Augustyna, SACh SN 12, Katowice 2012.

Kelly J.N.D., Poczatki doktryny chrześcijańskiej, thum. J. Mrukówna, Warszawa 1988.

Konieczny M., Pocatunek pokoju, EK XV 901-902.

LiBERA P., Zasadnicze aspekty metody hermeneutycznej św. Ambrożego z Mediolanu, SSHT 25-26 (1992-1993) 19-27.

MŁотек A., Jałmużna, EK VII 738-741.

Pietras H., Poczatki teologii Kościoła, Kraków 2000.

SANTORSKi A., Eklezjologiczne elementy mariologii świętego Ambrożego, VoxP 18 (1998) t. $34-35,119-127$.

Simon M., Cywilizacja wczesnego chrześcijaństwa I-IV w., thum. E. Bąkowska, Warszawa 1981.

Simonetti M., Między dosłownościq a alegoriq. Przyczynek do historii egzegezy patrystycznej, tłum. T. Skibiński, Kraków 2000.

SoŁomieniuk M., Motyw płaczu w mowach żałobnych św. Ambrożego, TPatr 7 (2010) 105-126.

Szczur P., Marcelina, EK XI 1226.

Tissot G., Introduction, w: SCh 45, Paris 1956, 9-37.

WipszycKa E., Kościół w świecie późnego antyku, Warszawa 1994.

ZAGÓRSKI D., Przebieg aktu pokutnego na podstawie „,Komentarza do Psalmu XXXVII”, św. Ambrożego, RT 53 (2006) z. 4, 171-183.

Zelzer M., „Imperator intra ecclesiam non supra ecclesiam est” (Ambrosius, Epistula 75a,36), VoxP 18 (1998) t. 34-35, 219-226. 
